\title{
Reliability of beams designed in accordance with Brazilian codes
}

\section{Confiabilidade de vigas projetadas de acordo com as normas brasileiras}
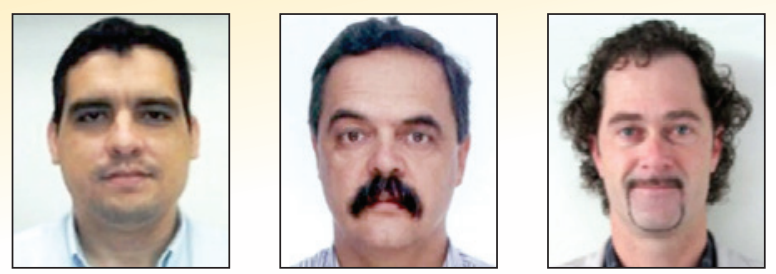

D. M. SANTOS a

danielmiranda@usp.br

F. R. STUCCHI

fernando.stucchi@poli.usp.br

A. T. BECK ${ }^{\mathrm{C}}$ atbeck@sc.usp.br

\begin{abstract}
This paper presents an investigation on the safety of structural elements submitted to pure bending, produced in reinforced concrete, in steel and steel-concrete composites, and designed according to Brazilian codes NBR8681:2003, NBR6118:2007 and NBR8800:2008. The study allows a comparison of the relative safety of beams produced with these materials and designed using these codes. Comparative studies between the performances of different materials are difficult to find in the published literature. The present study shows that reliability indexes for reinforced concrete beams are satisfactory; however, results for steel beams are below limit values established in international design standards. Reliability indexes found herein for steel-concrete composite beams are intermediate to concrete and steel beams.
\end{abstract}

Keywords: beam, reinforced concrete, steel, composite structures, reliability, safety.

\section{Resumo}

Este artigo apresenta uma investigação da segurança de elementos estruturais submetidos à flexão simples, em concreto armado, em aço e em material misto, e dimensionados segundo as normas NBR8681:2003, NBR6118:2007 e NBR8800:2008. O estudo permite uma comparação da segurança relativa de vigas produzidas com estes materiais e através destas normas. Estudos comparativos entre diferentes materiais são raros na literatura. Resultados da presente investigacão mostram que, enquanto os índices de confiabilidade dos elementos de concreto são satisfatórios, as vigas metálicas apresentam resultados abaixo dos limites estabelecidos por normas internacionais. No caso das vigas mistas, os índices de confiabilidade encontrados estão entre os valores para concreto e aço.

Palavras-chave: vigas, concreto armado, aço, estruturas mistas, confiabilidade, segurança. 


\section{Introduction}

Brazilian standards for the design of building structures [1-10] are based on the limit state method. Uncertainties inherent to structural actions and strength of materials are indirectly considered through the use of partial safety factors. When properly evaluated, these partial factors should ensure adequate safety for the structure.

Nowadays, it is internationally recognized that the most rational way to assess the safety of a structure is assessing it probabilistically. Europe, with the EUROCODES, and the United States, with the Load and Resistance Factor Design, for example, already use structural reliability in the calibration of partial safety factors of their design standards.

In Brazil, there is little information regarding how safe are the structures designed using national standards. On the other hand, although using the limit state method, national standards have never been calibrated in order to obtain, for example, equivalent reliability in the design of structures using different materials [11] Some studies are found reporting the reliability of structural elements designed in reinforced concrete [12-16], steel [11, 17] or steel-concrete composites $[18,19]$. These studies do not report comparisons between the safety levels of structural elements produced with different materials, as is proposed in this study. This study uses statistical data used in the calibration of American [2022] and European standards [23-27] as well as some national data [16]. The study compares the reliability levels of reinforced concrete, steel and steel-concrete composite beams designed according to Brazilian standards.

\section{Brazilian structural building standards}

NBR8681 [1] is the head code that provides the general guidelines for the design of civil structures. This code establishes criteria and principles which, together with specific codes of actions (NBR6120 [5], NBR6123 [6], among others), guide the design of a building. In relation to the behavior and strength of structural building materials, specific standards must be observed: reinforced or prestressed concrete structures must meet the design and detailing criteria of NBR6118 [2]; steel buildings must meet NBR8800 [3]. There are also some "additional" standards such as NBR9062 [7] (precast concrete), NBR14762 [8] (cold formed members), as well as codes of structures exposed to fire (NBR15200 [9] and NBR14323 [10]).

NBR8681 [1] specifies partial factors, as well as the combination factors of actions to be used in the design of buildings. Specific standards of different structural materials should deal only with strength aspects such as partial safety factors, criteria on the behavior of structural materials, etc. Unfortunately, it has been observed in codes of structural materials [2, 3, $7-10$, among others] that there is duplicity of definitions concerning structural actions. According to the authors, the result of standard committees establishing conflicting requirements is even more serious. In our view, some conflicting definitions are due to gaps in the NBR 8681 [1] therefore, this code should be reviewed in order to standardize recommendations and eliminate discrepancies.

In this work, the reliability of beams submitted to bending according to NBR8681 [1], NBR6118 [2] and NBR8800 [3] standards is analyzed; the study addresses some of the divergent requirements mentioned above.

\section{Structural design according to Brazilian standards}

\subsection{Usual condition on ultimate design states}

In usual cases, the safety condition regarding the limit state of a structural element can be described as:

$$
\mathrm{R}_{\mathrm{d}} \geq \mathrm{S}_{\mathrm{d}}
$$

where $S_{d}$ is the design value of action effects and $R_{d}$ is the design strength of the structural element in relation to action $\mathrm{S}$.

\subsection{Actions}

The structural analysis must consider the influence of all actions that may have significant effects on the structure [2, 3]. Actions can be classified, for example, with respect to variation in time (permanent, variable and accidental), origin (direct or indirect), variation in space (fixed or mobile) and of nature or structural response (static and dynamic).

Permanent actions are those that act on the structure for a reference period, with negligible change in magnitude over time, or the variation is always in the same direction or until the action reaches a certain limit (monotonic action).

Variable actions are those that have variable duration, intensity or direction over time and that are non-monotonic. For example: live loads in buildings, wind and thermal actions.

Accidental actions are those that have very short duration and small probability of occurrence during the lifetime of a structure, but have significant intensity such as explosions, impact and high magnitude earthquakes.

In this work, only permanent and variable actions are considered. Moreover, permanent actions are considered grouped and only one variable action, the live load, is considered.

\subsection{Characteristic values of actions}

NBR8681 [1] defines the characteristic values of permanent actions as mean values, quantile $50 \%$, either when the effects are unfavorable, or when the effects are favorable. The probabilistic model for permanent actions usually is the normal distribution [20-26].

According to NBR8681 [1], the characteristic value of variable actions established by consensus and reported in specific codes correspond to values that have $25 \%$ to $35 \%$ probability of being exceeded in a period of 50 years. Although NBR8681 [1] defines the characteristic values of variables actions this way, there are to date no realistic statistical data in Brazil showing that the values defined in NBR6120 [5] are complying with this requirement. Therefore, a national mobilization for the survey of field data is needed in order to better understand the level of safety of structures built in Brazil. The type of actions addressed in this study is live load in buildings, commonly represented using Gumbel distributions [20, 22, 24 to 26]. Alternatively, stochastic models [23] are used, describing the temporal variation of these actions (not considered in this work). 


\subsection{Ultimate limit states load combinations}

Grouped permanent actions and variable action must be combined by the following expression:

$$
\mathrm{F}_{\mathrm{d}}=\gamma_{\mathrm{g}} \cdot \mathrm{F}_{\mathrm{gk}}+\gamma_{\mathrm{q}} \cdot \mathrm{F}_{\mathrm{qk}}
$$

where:

$F_{d}$ is the design value of actions;

$F_{g k}$ is the characteristic value of grouped permanent actions;

$\mathrm{F}_{\mathrm{qk}}$ is the characteristic value of variable action;

$\gamma_{g}$ and $\gamma_{q}$ are the partial factors of permanent and variable actions respectively.

Importantly, in expression (2), the partial factors should multiply the actions, and not the effects of actions. However, in the case of linear structural analysis (1 $1^{\text {st }}$ order effects), the superposition principle is valid, and in this case, the effects of actions can be combined using the partial factors. Thus, the ultimate combination equation becomes:

$$
\mathrm{S}_{\mathrm{d}}=\gamma_{\mathrm{g}} \cdot \mathrm{G}_{\mathrm{k}}+\gamma_{\mathrm{q}} \cdot \mathrm{Q}_{\mathrm{k}}
$$

where:

$S_{d}$ is the design action effect;

$G_{k}$ is the characteristic value of the permanent action effect;

$Q_{k}$ is the characteristic value of variable action effect.

Equation (3) must be applied to each type of action effect to which a structural element is submitted (bending moment, shear effort, torque, etc).

The partial factors for actions, according to NBR8681 [1], are shown in Table 1.

NBR6118 [2] establishes a value for the partial factors of permanent and variable actions: $\gamma_{g}=\gamma_{q}=1.4$, except for the case of prefabricated concrete structures.

\begin{tabular}{|c|c|c|}
\hline \multicolumn{3}{|c|}{$\begin{array}{l}\text { Table } 1 \text { - Partial factors for actions according to } \\
\text { NBR8681 (1) for normal ultimate combination }\end{array}$} \\
\hline Type of structure & $\gamma_{g}$ & $\gamma_{q}$ \\
\hline Large bridges* & 1.30 & 1.50 \\
\hline $\begin{array}{l}\text { Type } 1 \text { buildings** and } \\
\text { bridges in general }\end{array}$ & 1.35 & 1.50 \\
\hline Type 2 buildings *** & 1.40 & 1.40 \\
\hline \multicolumn{3}{|c|}{$\begin{array}{l}\text { * The weight of the structure is at least } 75 \% \text { the permanent load } \\
\text { **Buildings where variables actions are at least } 5 \mathrm{kN} / \mathrm{m}^{2} \\
\text { ***Buildings where variables actions are less than } 5 \mathrm{kN} / \mathrm{m}^{2}\end{array}$} \\
\hline
\end{tabular}

NBR8800 [3] prescribes the same values of NBR8681 [1] for per- manent action coefficients (when grouped) and a single value for the variable load partial factor: $\gamma_{\mathrm{q}}=1.5$.

\subsection{Characteristic values of the strength of materials}

The characteristic values $f_{k}$ of the strength of materials are those that in a lot of materials have a certain probability of being exceeded against safety [1]. For the ultimate limit state, this probability is usually equal to $5 \%$. Assuming normal distribution, the usual case of concrete and steel, the characteristic value is defined by:

$$
\mathrm{f}_{\mathrm{k}}=\mu_{\mathrm{f}}-1,645 \cdot \sigma_{\mathrm{f}}
$$

where:

$\mu_{f}$ is the mean strength;

$\sigma_{f}$ is the standard deviation of material strength.

\subsection{Design strength of flexed elements subject to bending}

\subsubsection{Reinforced concrete beams}

The resisting moment $\left(\mathrm{M}_{\mathrm{rd}}\right)$ of a rectangular singly reinforced beam (Figure 1) is:

$$
M_{r d}=A_{s} \cdot \frac{f_{y k}}{\gamma_{s}}\left(h-d^{\prime}-0,5 \cdot \frac{A_{s} \cdot f_{y k} / \gamma_{s}}{0,85 \cdot b \cdot f_{c k} / \gamma_{c}}\right)
$$

where:

$A_{s}$ - area of reinforcing steel;

$f_{y k}$ - characteristic yield strength of reinforcement;

$f_{c k}$ - characteristic strength of concrete in compression;

$\mathrm{h}$ - section height;

d'- distance from the bottom face of the concrete to the steel bar axis;

\section{Figure 1 - Rectangular cross-section of reinforced} concrete with simple reinforcement

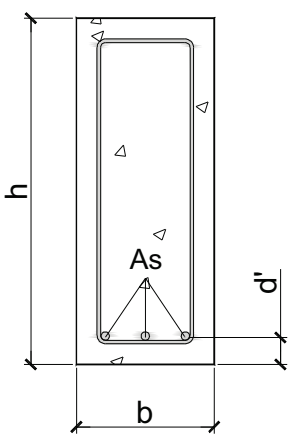


b - section width;

$\gamma_{s}$ and $\gamma_{c}$ - reinforcement and concrete partial factors, respectively. Equation (5) is valid only for domains 2 and 3 , i.e., when the reinforcement is in plastic regime in the ultimate limit state.

\subsubsection{Laterally restrained steel beam with compact section}

The resisting moment $\left(\mathrm{M}_{\mathrm{rd}}\right)$ of a laterally restrained steel beam with compact section (classes 1 and 2 ) is given by:

$$
\mathrm{M}_{\mathrm{rd}}=\mathrm{Z} \cdot \frac{\mathrm{f}_{\mathrm{y}}}{\gamma_{\mathrm{a} 1}}
$$

where:

Z - plastic section bending modulus;

$\mathrm{f}_{\mathrm{y}}$ - characteristic yield strength of structural steel;

$\gamma_{\mathrm{a} 1}$ - partial safety factor.

\subsubsection{Steel-concrete composite beam}

The resisting moment $\left(\mathrm{M}_{\mathrm{rd}}\right)$ of a steel-concrete composite beam (Figure 2), with plastic neutral axis in the concrete beam, is given by:

$$
M_{r d}=A_{a} \cdot \frac{f_{y}}{\gamma_{a} 1}\left(d_{s}+h_{c}-0,5 \cdot \frac{A_{a} \cdot f_{y} / \gamma_{a}}{0,85 \cdot b_{c} \cdot f_{c k} / \gamma_{c}}\right)
$$

where:

d - section height;

$d_{s}$ - distance between the center of gravity and the extreme top fiber of the steel section;

$A_{a}$ - area of the steel section;

$\mathrm{h}_{\mathrm{c}}$ - concrete slab height;

$b_{c}$ - effective width of concrete slab.

The partial factors for strength are shown in Table 2.

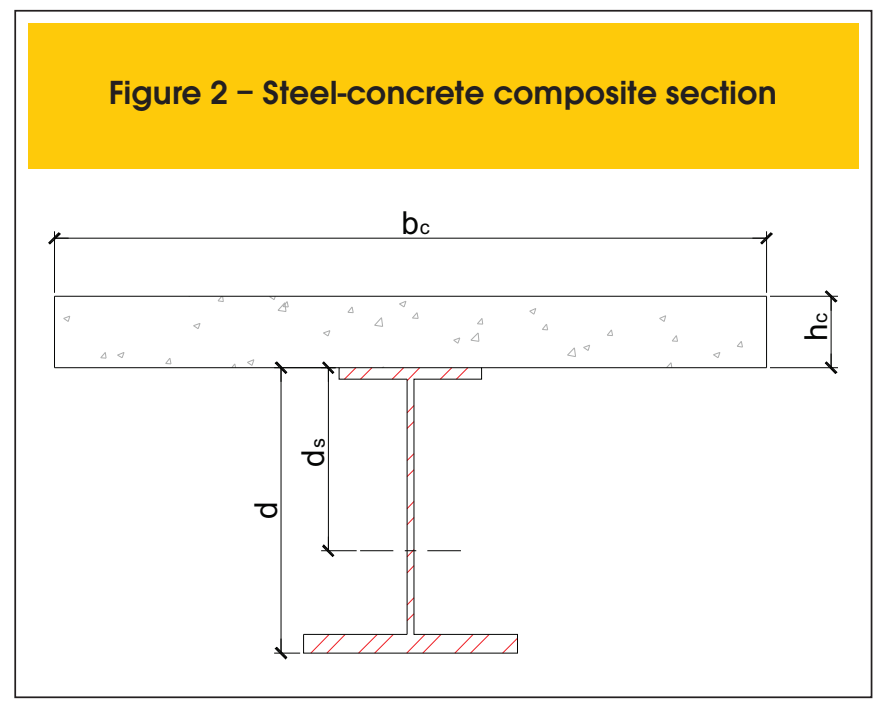

\section{Principles of reliability analysis}

The reliability analysis of the structural element under study (beam submitted to pure bending) consists of assessing the failure probability (or reliability index) over the lifetime of the structure. A limit state in a probabilistic analysis can be described in terms of a performance function, defined by:

$$
g(X)=R(X)-S(X)
$$

where:

$X$ - vector of random variables of the problem;

$R(X)$ - random variable representing the strength of the structural element;

$S(X)$ - random variable representing the action or requesting effort. The limit state is defined as the event $g(X)=0$; and the failure probability is given by:

$$
\mathrm{P}_{\mathrm{f}}=\mathrm{P}[\mathrm{g}(\mathrm{X})<0]
$$

Once the failure event is defined, the probability of failure is evaluated as [28]:

$$
P_{f}=\int_{G(x) \leq 0} f_{X}(x) d x
$$

where $f_{x}(x)$ is the joint density function of the random variables and $x \mid g(x) \leq 0$ is the failure domain. There are several methods to solve this integral. In general, the techniques are characterized by their level of sophistication and can be defined as:

- Fully probabilistic methods that consider the joint distribution of all random variables. Reliability is directly associated with the failure probability (e.g., numerical integration, Monte Carlo simulation);

- Fully probabilistic methods using approximations. Reliability is not directly associated with a probability, but with a fixed index known as reliability index $(\beta)$. It is assumed that the failure probability associated with the reliability index is $P_{f} \cong \Phi(-\beta)$, where $\Phi$ $(\cdot)$ is the cumulative distribution function of a standard normal

\begin{tabular}{|cc|}
\hline $\begin{array}{c}\text { Table 2 - Partial factors for resistance } \\
\text { (NBR6118 [2] and NBR8800 [3]) }\end{array}$ \\
Material & $\gamma_{R}$ \\
Concrete & 1.40 \\
Reinforcing steel & 1.15 \\
Structural steel & 1.10 \\
\hline
\end{tabular}




\section{Table 3 - Rectangular reinforced concrete cross-sections analyzed and design resistance considering $\mathrm{C} 25$ concrete $\left(f_{c k}=25 \mathrm{MPa}\right), \mathrm{CA}-50$ steel $\left(\mathrm{f}_{\mathrm{yk}}=500 \mathrm{Mpa}\right)$ and partial factors $\gamma_{c}=1.4$ and $\gamma_{s}=1.15$}

\begin{tabular}{ccccccccc} 
Reinforcement & $\mathbf{A}_{\mathrm{s}}\left(\mathbf{c m}^{2}\right)$ & $\mathbf{b}(\mathbf{c m})$ & $\mathbf{h}(\mathbf{c m})$ & $\rho(\%)$ & $\mathbf{d}^{\prime}(\mathbf{c m})$ & $\mathbf{x} /\left(\mathbf{h}-\mathbf{d}^{\prime}\right)$ & $\mathbf{R}_{\mathrm{d}}=\mathbf{M}_{\text {rd }}(\mathbf{k N} \cdot \mathbf{m})$ \\
$3 \phi 8 \mathrm{~mm}$ & 1.5 & 20 & 50 & 0.15 & 3.9 & 0.058 & 29.36 \\
$4 \phi 10 \mathrm{~mm}$ & 3.2 & 20 & 50 & 0.32 & 4.0 & 0.125 & 60.81 \\
$4 \phi 12,5 \mathrm{~mm}$ & 5.0 & 20 & 50 & 0.50 & 4.1 & 0.195 & 92.00 \\
$4 \phi 16 \mathrm{~mm}$ & 8.0 & 20 & 50 & 0.80 & 4.3 & 0.313 & 139.03 \\
$3 \phi 20 \mathrm{~mm}$ & 9.45 & 20 & 50 & 0.95 & 4.5 & 0.327 & 159.14 \\
\hline
\end{tabular}

random variable, i.e., whose mean is equal to 0 and standard deviation is equal to 1 (e.g. FORM and SORM);

- Semi-probabilistic analysis or limit state method. Safety is introduced by a careful choice of representative values of actions and through partial safety factors that should cover not only uncertainties associated with the chosen values, but also uncertainties related to the models for actions and strengths. No probability is calculated or estimated.

In this work, the First Order Reliability Method (FORM) described in $[30,31]$ is used. Some design situations were verified via Monte Carlo simulation, with obtained results very close to FORM. This shows that the limit state equations are weakly nonlinear in the vicinity of the design point.

\section{Sections analyzed}

\subsection{Reinforced concrete beams}

A reinforced concrete cross-section is adopted which is very common in buildings with usual distance from five to six meters between columns: $20 \mathrm{~cm}$ in width (b) and $50 \mathrm{~cm}$ in height (h). Several reinforcement ratios are considered in the assessment of structural reliability, following Table 3 .

The data used for reliability analysis are show in Table 3. All beams were evaluated with $\mathrm{C} 25$ concrete $\left(f_{c k}=25 \mathrm{MPa}\right)$ and CA-50 steel $\left(f_{y k}=500 \mathrm{MPa}\right)$. The assumption that concrete is compliant was used, but this may not reflect the reality of concrete structures produced in Brazil [see 15].

Interestingly, in the case of $\mathrm{CA}-50$ reinforcement with par- tial factor $\gamma_{s}=1.15$, the limit between domains 3 and 4 is $\mathrm{x} /\left(\mathrm{h}-\mathrm{d}^{\prime}\right)=0.628$.

\subsection{Reinforced concrete slabs}

A slab with thickness of $10 \mathrm{~cm}$ and reinforcement ratios ranging from $0.15 \%$ to $0.95 \%$ (Table 4 ) is considered. The materials used are the same for the beam, namely, C25 concrete and CA-50 steel.

\subsection{Steel beams}

In this study, it is assumed that the variability of geometrical properties is negligible, or so small that it can be incorporated in the variability of material properties (Table 6 shows that the standard deviation is higher in structural steel than in reinforcement steel). Thus, since the strength of the steel section (Eq. (6)) varies linearly with the plastic modulus, the reliability indexes are independent of $Z$, i.e., independent of the section geometry.

\subsection{Steel-concrete composite beams}

For steel-concrete composite sections, the lightest and heaviest steel sections of the same series were compared (VSM400x33 and VSM400x46) always assuming the same effective width of concrete slab $\left(b_{c}=250 \mathrm{~cm}\right)$ and same slab thickness $\left(h_{c}=10 \mathrm{~cm}\right)$, according to Table 5 .

The plastic neutral axis (PNA) is always located in the concrete $\operatorname{slab}\left(\mathrm{a}_{\mathrm{c}}<10 \mathrm{~cm}\right)$.

\section{Table 4 - Sections of concrete flat slab analyzed and design resistance considering C25 concrete $\left(f_{c k}=25 \mathrm{MPa}\right), \mathrm{CA}-50$ steel $\left(\mathrm{f}_{\mathrm{yk}}=500 \mathrm{Mpa}\right)$ and partial factors $\gamma_{c}=1.4$ and $\gamma_{s}=1.15$}

\begin{tabular}{cccccccc} 
Reinforcement & $\mathbf{A}_{\mathrm{s}}\left(\mathrm{cm}^{2} / \mathbf{m}\right)$ & $\mathbf{h}(\mathbf{c m})$ & $\rho(\%)$ & $\mathbf{d}^{\prime}(\mathbf{c m})$ & $\mathbf{x} /\left(\mathbf{h}-\mathbf{d}^{\prime}\right)$ & $\mathbf{R}_{\mathrm{d}}=\mathbf{M}_{\mathrm{rd}}(\mathbf{k N} \cdot \mathbf{m})$ \\
\hline Minimum & 1.5 & 10 & 0.15 & 4.0 & 0.090 & 3.77 \\
$\phi 6,3 \mathrm{c} / 10$ & 3.2 & 10 & 0.32 & 4.0 & 0.191 & 7.71 \\
$\phi 8 / 10$ & 5.0 & 10 & 0.50 & 4.0 & 0.298 & 11.49 \\
$\phi 10 \mathrm{c} / 10$ & 8.0 & 10 & 0.80 & 4.0 & 0.477 & 16.88 \\
$\phi 12.5 \mathrm{c} / 12.5$ & 9.45 & 10 & 0.95 & 4.0 & 0.597 & 19.86 \\
\hline
\end{tabular}




\section{Table 5 - Steel-concrete composite sections analyzed and design resistance considering \\ C25 concrete $\left(f_{c k}=25 \mathrm{Mpa}\right)$ CA-50 steel $\left(f_{y k}=500 \mathrm{Mpa}\right)$ \\ and partial factors $\gamma_{c}=1.4$ e $\gamma_{s}=1,15$}

\begin{tabular}{|c|c|c|c|c|c|c|}
\hline Section designation & $A_{a}\left(\mathrm{~cm}^{2}\right)$ & $D_{s}(\mathrm{~cm})$ & $b_{c}(\mathrm{~cm})$ & $h_{c}(\mathrm{~cm})$ & $a_{c}(\mathrm{~cm})$ & $R_{\mathrm{d}}=\mathrm{M}_{\mathrm{rd}}(\mathrm{kN} \cdot \mathrm{m})$ \\
\hline VSM400×33 & 42.6 & 21.27 & 250 & 10 & 2.5 & 29.04 \\
\hline VSM400×46 & 59.0 & 22.82 & 250 & 10 & 3.53 & 41.64 \\
\hline
\end{tabular}

\section{Reliability analysis of beams subject to pure bending}

The general procedure for reliability analysis is shown in the flowchart of Figure 3.

The first step is to select the structural element and type of cross section to be analyzed. After defining the cross section, the design strength $\left(R_{d}\right)$ is determined by means of an "economic" design, the same value for the action effect is assumed.

To transform the action effect into characteristic values of each action, it is necessary to define the relationship between permanent and variable loads. This can be achieved by the following expression:

$$
\chi=\frac{Q_{k}}{G_{k}+Q_{k}}
$$

Therefore,

$$
\mathrm{G}_{\mathrm{k}}=\frac{\mathrm{S}_{\mathrm{d}}}{\gamma_{\mathrm{g}}+\gamma_{\mathrm{q}} \cdot \chi /(1-\chi)}
$$

$$
Q_{k}=\frac{S_{d}}{\gamma_{g} \cdot(1-\chi) / \chi+\gamma_{q}}
$$

After determining the characteristic or nominal values, the statistical parameters of each random variable are evaluated and, finally, the reliability analysis is made. For the sections analyzed, the performance functions are:

- Reinforced concrete rectangular section:

$$
g(X)=\theta_{R} \cdot A_{s} \cdot f_{y}\left(h-d^{\prime}-0,5 \cdot \frac{A_{s} \cdot f_{y}}{0,85 \cdot b \cdot f_{c}}\right)-\theta_{S}\left(M_{g}+M_{q}\right)
$$

Steel section:

$$
g(X)=\theta_{R} \cdot Z \cdot f_{y}-\theta_{S}\left(M_{g}+M_{q}\right)
$$

Steel-concrete composite section:

$$
g(X)=\theta_{R} \cdot A_{a} \cdot f_{y}\left(d_{s}+h_{c}-0,5 \cdot \frac{A_{a} \cdot f_{y}}{0,85 \cdot b \cdot f_{c}}\right)-\theta_{S}\left(M_{g}+M_{q}\right)
$$

where:

$\theta_{R}$ is the uncertainty in resistance model; $\theta_{S}$ is the uncertainty in load model.

Figure 3 - Reliability analysis flowchart

Choice of structural element and cross-section to be analyzed

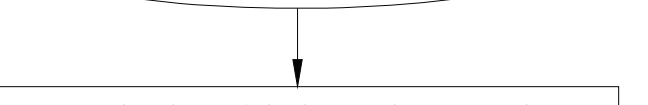

Evaluation of design resistance $\mathrm{Rd}$ according to NBR6118 [2] or NBR8800 [3]

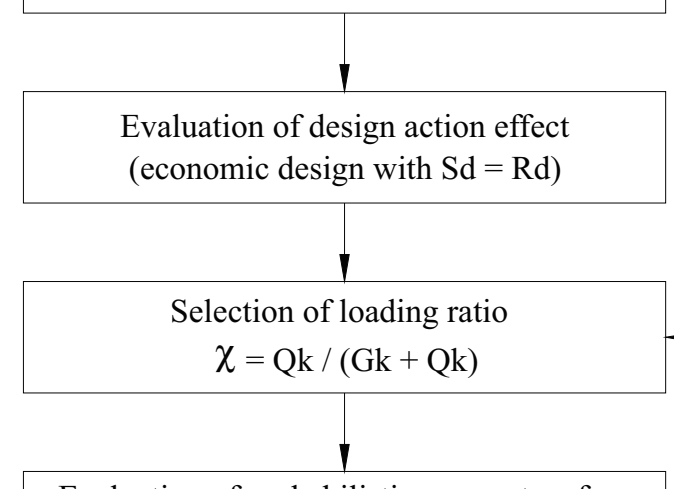

Evaluation of probabilistic parameters for

$$
\begin{gathered}
\text { G, Q given } \chi \\
\text { G Normal } \\
\text { Q Gumbel }
\end{gathered}
$$
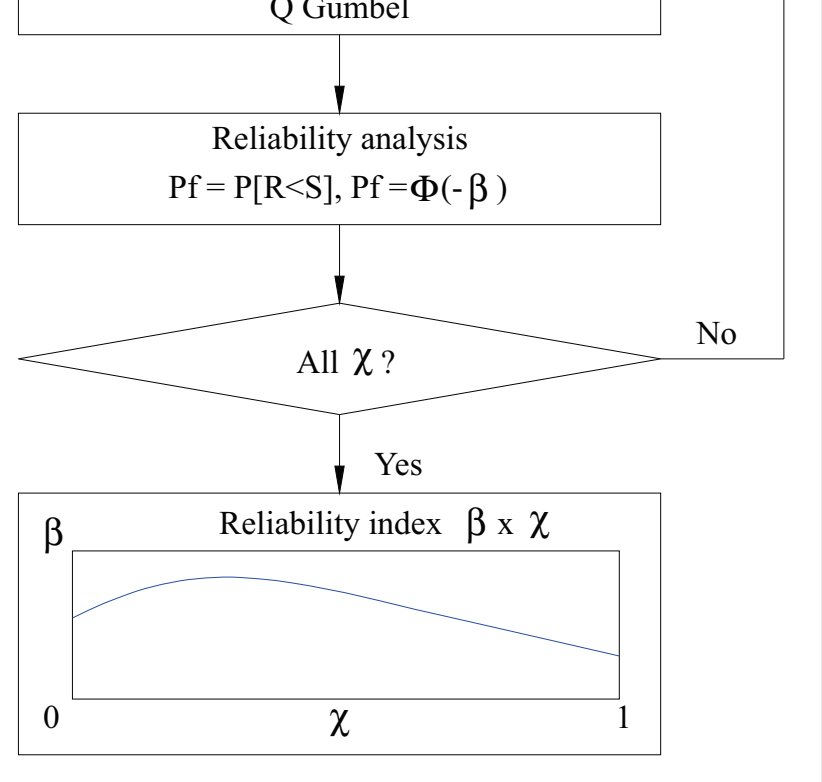


\section{Table 6 - Probabilistic models of random variables for reliability analysis}

\begin{tabular}{|c|c|c|c|c|c|c|}
\hline Category of variables & Name of basic variables & Simb. & Dimension & Distribution & $\mu_{\mathrm{x}}$ & $\sigma_{\mathrm{x}}$ \\
\hline Actions & $\begin{array}{c}\text { Permanent } \\
\text { Variable Action - } 50 \text { years }\end{array}$ & $\begin{array}{l}G \\
Q\end{array}$ & $\begin{array}{l}\mathrm{kN} \cdot \mathrm{m} \\
\mathrm{kN} \cdot \mathrm{m}\end{array}$ & $\begin{array}{l}\text { Normal } \\
\text { Gumbel }\end{array}$ & $\begin{array}{c}G_{k} \\
0.93 Q_{k}\end{array}$ & $\begin{array}{l}0.1 \mu_{x} \\
0.2 \mu_{x}\end{array}$ \\
\hline Strength of materials & $\begin{array}{l}\text { Concrete } \\
\text { Passive steel for concrete } \\
\text { Structural steel for profile }\end{array}$ & $\begin{array}{l}f_{c} \\
f_{y} \\
f_{y}\end{array}$ & $\begin{array}{l}\mathrm{MPa} \\
\mathrm{MPa} \\
\mathrm{MPa}\end{array}$ & $\begin{array}{l}\text { Normal } \\
\text { Normal } \\
\text { Normal }\end{array}$ & $\begin{array}{l}1.17 f_{c k} \\
1.08 f_{y k} \\
1.08 f_{y}\end{array}$ & $\begin{array}{l}0.15 \mu_{x} \\
0.05 \mu_{x} \\
0.08 \mu_{x}\end{array}$ \\
\hline \multirow{6}{*}{ Geometric data } & Concrete beam height & $\mathrm{h}$ & $\mathrm{cm}$ & Normal & 50 & 2.25 \\
\hline & Concrete beam width & $b$ & $\mathrm{~cm}$ & Normal & 20 & 1.20 \\
\hline & CG Dist. from bar (lower fiber - beam) & $d^{\prime}$ & $\mathrm{cm}$ & LN & $d_{n o m}^{\prime}$ & 1.10 \\
\hline & CG Dist. from bar (lower fiber - slab) & $d^{\prime}$ & $\mathrm{cm}$ & LN & 4 & 0.60 \\
\hline & CG Dist. from bar (upper fiber - beam) & $d^{\prime}$ & $\mathrm{cm}$ & LN & 4 & 1.10 \\
\hline & Concrete slab height & $h_{c}$ & $\mathrm{~cm}$ & Normal & 10 & 0.60 \\
\hline Load uncertainties & Uncertainties in action effect model & $\theta_{\mathrm{s}}$ & - & LN & 1.00 & 0.05 \\
\hline \multirow{4}{*}{$\begin{array}{c}\text { Resistance } \\
\text { uncertainties }\end{array}$} & Concrete beam - Flexure & $\theta_{R}$ & - & LN & 1.00 & 0.05 \\
\hline & Concrete slab - Flexure & $\theta_{R}$ & - & LN & 1.00 & 0.05 \\
\hline & Steel beam - Flexure & $\theta_{R}$ & - & LN & 1.00 & 0.03 \\
\hline & Steel-concrete composite beam - Flexure & $\theta_{\mathrm{R}}$ & - & LN & 1.00 & 0.05 \\
\hline
\end{tabular}

\section{Probabilistic models}

The statistical parameters and distributions of each random variable are summarized in Table 6 . These data were obtained from several references [20 to 27] and compared with some national database [16].

In the case of compressive concrete strength, it was considered that the coefficient of variation of material obtained from a given location is $10 \%$ (related to the characteristic design value), but in the structure, the coefficient of variation is different (due to the concreting and curing process) and the value assumed in Table 6 was equal to $15 \%$.

\section{Results}

The results obtained for the reinforced concrete sections designed using partial factors of NBR6118 [2] and NBR8681 [1] for type 2 buildings are shown in Figure 4.

Figure 4 shows that the reliability index depends on the reinforcement ratio of the section. The reliability of a reinforced concrete beam increases with increasing reinforcement ratios, since the steel strength variability is smaller than the concrete strength variability.

Based on Figure 4, the worst scenario is the situation where the variable action $\left(Q_{k}\right)$ is relatively large in relation to the permanent action $\left(G_{k}\right)$. The usual case of $\chi$ for reinforced concrete beams is between 0.1 and $0.6^{1}$ and for beams designed by NBR6118 [2], the reliability index for $\chi=0.6$ and $\rho=0.15 \%$ is 3.35 . This value is slightly lower than the limit value given by the American standard $\mathrm{ACl}$ [22], which is 3.5, and also by EUROCODE [29], which is 3.8. One alternative to increase reliability for larger load ratios is to design the beam using partial factors of NBR8681 [1] for type 1 buildings. Figure 5 shows that when parameter $\chi$ is large, this combination provides greater reliability.
The most suitable way of obtaining reliability indexes more uniform than those shown in Figures 4 and 5 is to decrease the partial factor of permanent actions $\left(\gamma_{g}\right)$ and increase the partial factor of variable actions $\left(\gamma_{\mathrm{o}}\right)$, according to the American standard [20] and as obtained in [11].

Our initial goal is to have a full assessment of the reliability of all the usual structural elements to then propose a set of changes aiming to homogenize reliability in all design configurations. Two

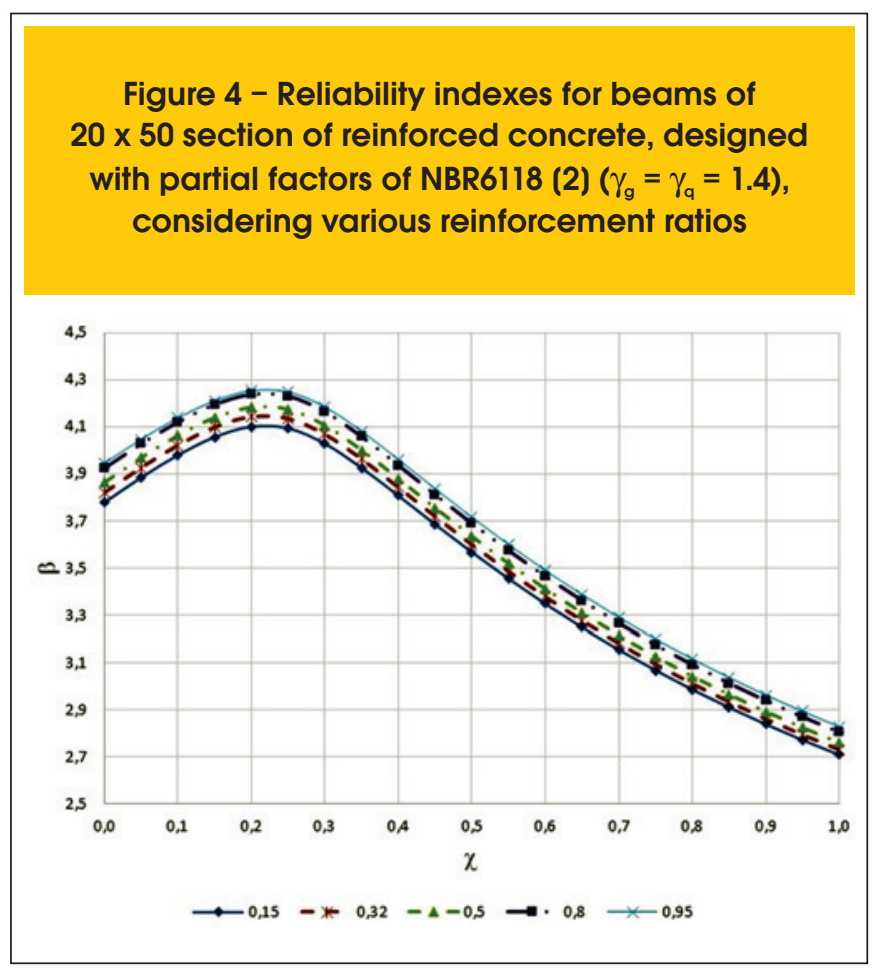




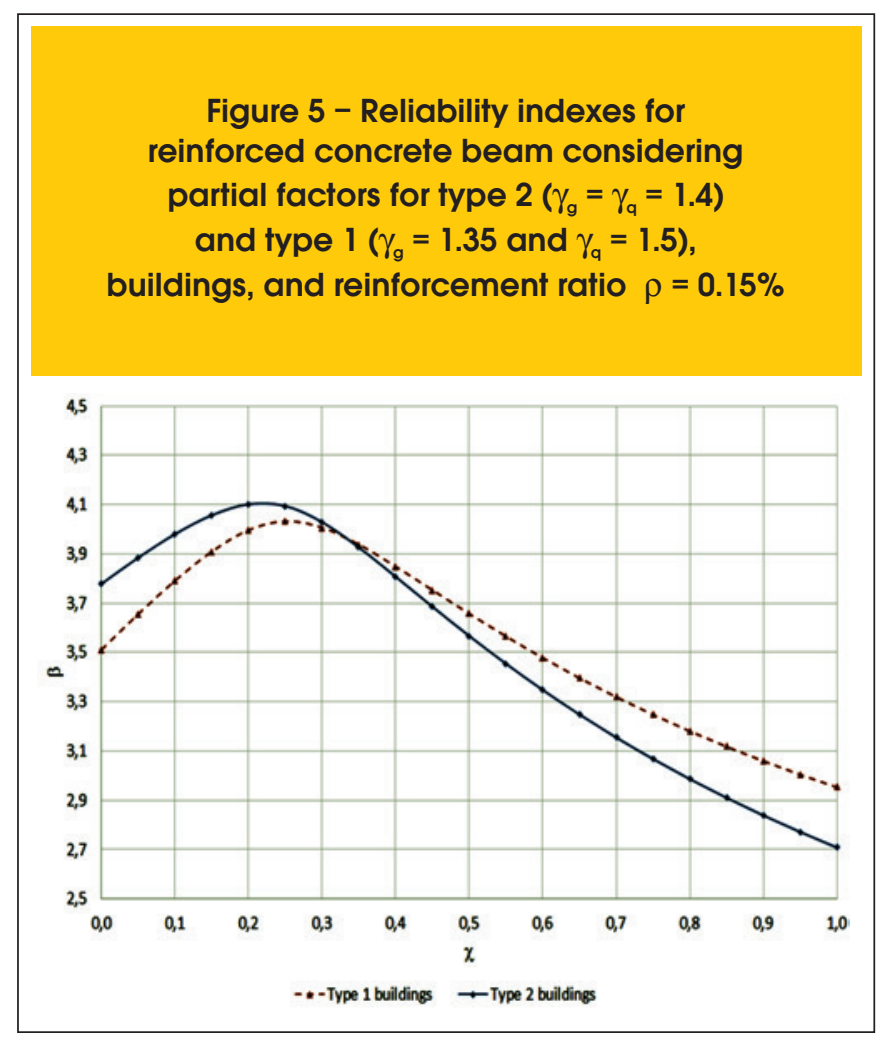

more urgent cases have already being indentified, where modifications have been proposed and approved in the latest revision of the NBR 6118 standard: cantilever concrete slabs and columns with 12 to $15 \mathrm{~cm}$ in thickness as described in [13].

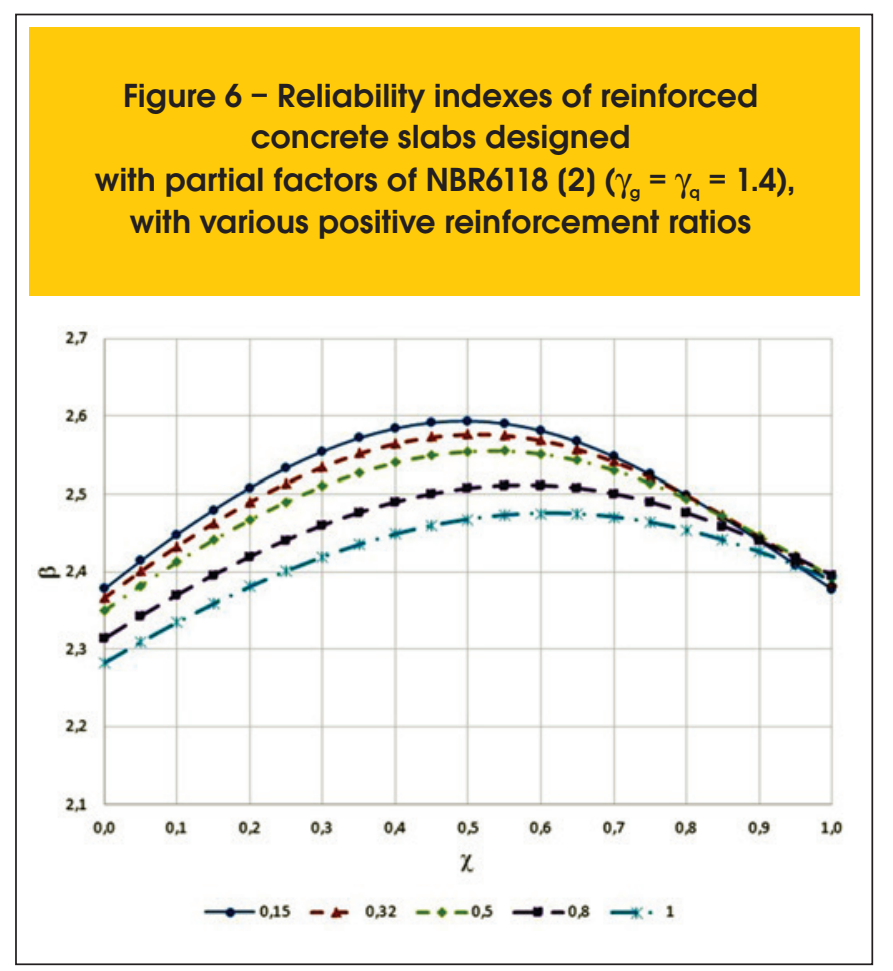

For slabs with positive moments, results shown in Figure 6 were obtained. The values of reliability indexes obtained are low, but in the case of highly hyper-static slabs, the value of 2.5 is allowed by $\mathrm{ACl}$ [22]. As in this work, the reliability assessment is based on one section and not on the structural element as a whole (a common practice in the calibration of standards), the indexes obtained for slabs are nominal: it is known that the actual reliability indexes will be higher due to the redistribution of internal forces. However, given the complexity of a probabilistic analysis in a two-dimensional element that has high rotation capacity, the practical recommendation of limiting the reliability index of a slab section to 2.5 will be assumed.

In the case of cantilevered slabs, where the ability to redistribute internal forces is limited or null, the ideal situation would be to have reliability index of 3.8 as EUROCODE [29] or equivalent to beams $(\beta=3.5)$ of $\mathrm{ACl}$ [22]. However, Figure 7 shows that, with greater variability in the position of the negative reinforcement, the reliability indexes are low, highlighting the inadequate safety of cantilevered slabs.

The low reliability indexes for cantilever slabs had already been discussed in [12] and the proposal for additional safety factor was discussed. The project for the review of NBR6118 [4] provides that for slabs with thicknesses smaller than $19 \mathrm{~cm}$, an additional coefficient $\gamma_{n}$ should be applied, according to expression:

$$
\gamma_{\mathrm{n}}=1,95-0,05 \cdot \mathrm{h}
$$

For this example, for a $10-\mathrm{cm}$ thick slab, the additional coefficient

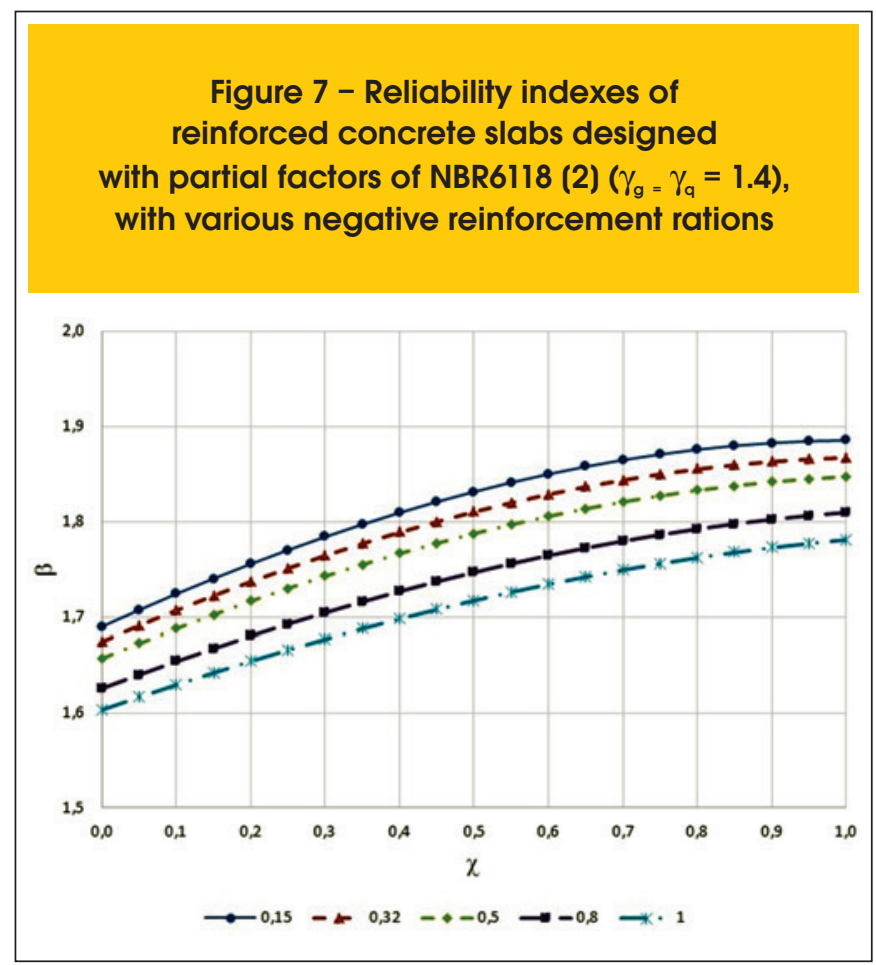




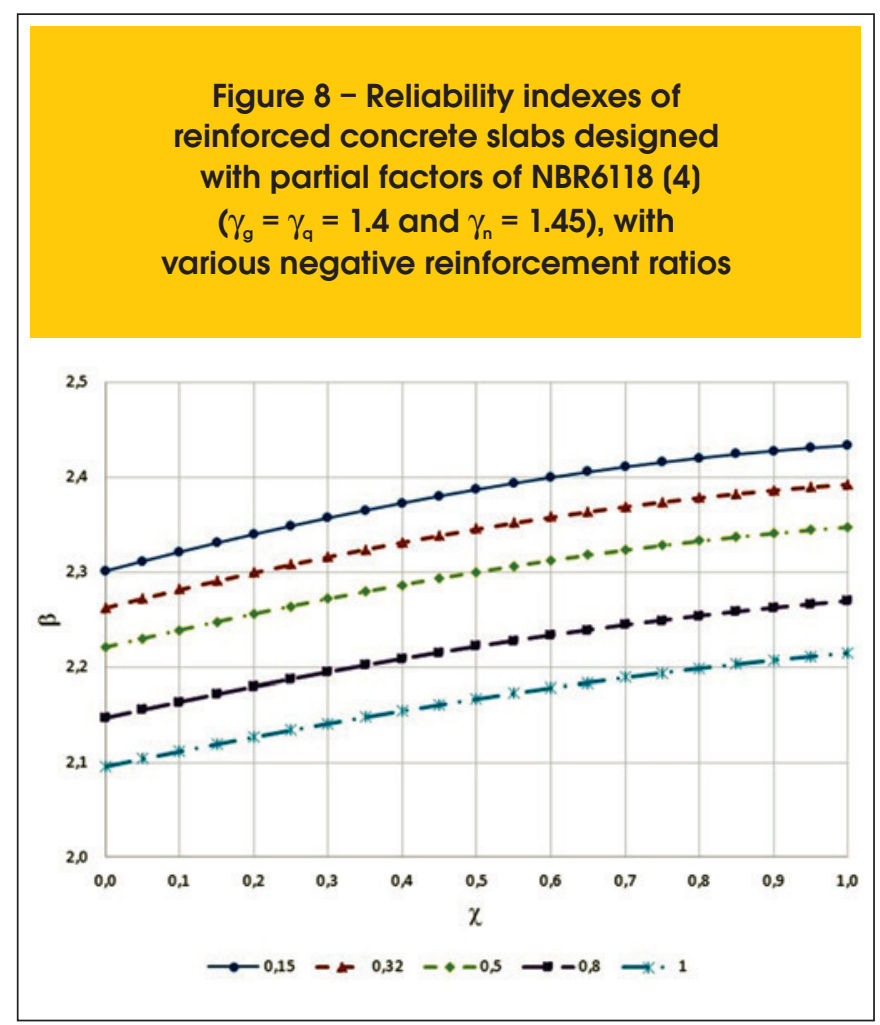

is $\gamma_{n}=1.45$. Figure 8 shows the effect of this factor on the reliability indexes. Although improved, the values are still low.

It is interesting that the results obtained for slabs show that reliability indexes generally decreases with increasing reinforcement

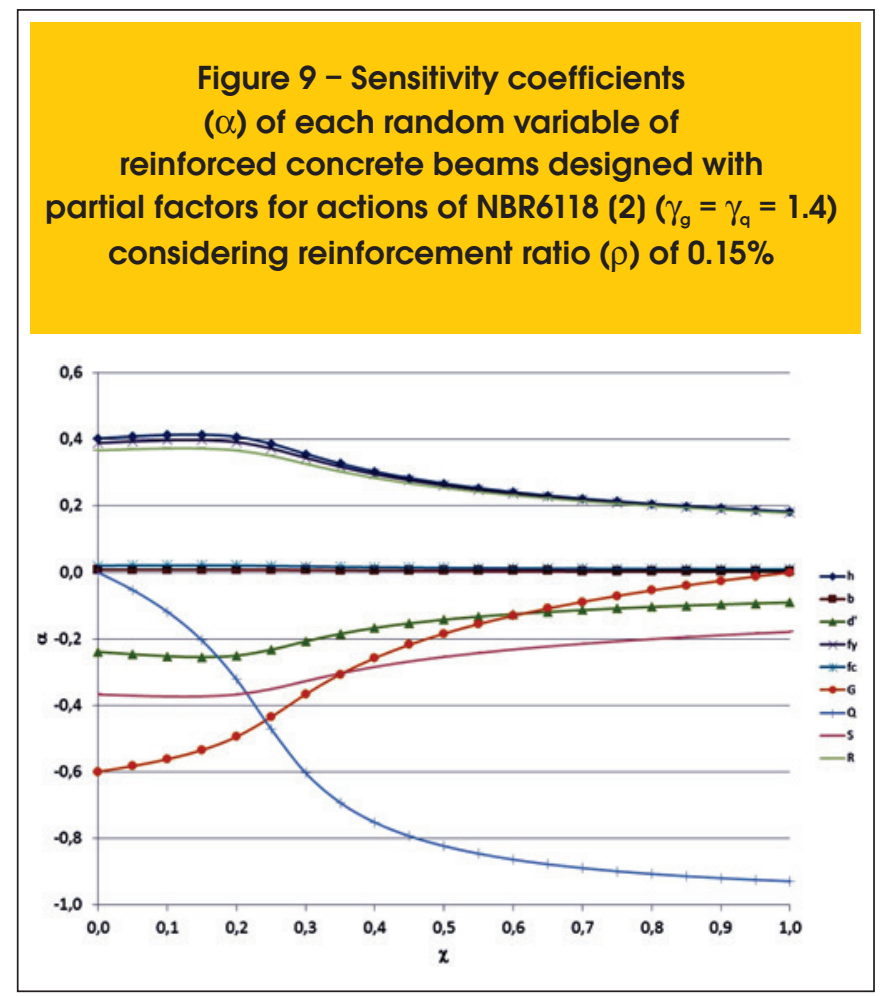

ratio. The justification for this behavior to be different from the results obtained for concrete beams is that the section height is small and the reinforcement position ( $d$ ' $=h-d$ which is $40 \%$ the height) is highly variable. This means that the most sensitive parameters in the reliability analysis of beams and concrete slabs are different, as observed by comparing the sensitivity coefficients of both analyses. These coefficients show which random variables have the greatest contribution in calculated failure probabilities. If $\alpha_{i}$ is the sensitivity coefficient of the $i^{\text {th }}$ random variable, then $\sum \alpha_{i}^{2}=1$. For loading variables, the coefficient is negative; for resistance variables, the coefficient is positive.

In Figure 9, referring to the concrete beam, it was observed that the permanent action $\mathrm{G}$ is the most important variable when $\chi$ is small and, on the other hand, variable action $Q$ becomes the most important variable when $\chi$ is large. For large $\chi$, the random variable $Q$ has sensitivity coefficient much greater than the other variables. However, when $\chi$ is small, $\mathrm{G}$ does not have the same influence and other random variables such as $h, f_{y}, \theta_{R}$ and $\theta_{s}$ also have some influence. This is evident to the extent that $\chi$ grows and sensitive indexes of these variables become smaller.

In the case of slabs (Figure 10), the random variable with the highest contribution to the failure probability is the reinforcement position d' and therefore, the behavior of reliability index of slabs and beams is distinct. The sensitivity coefficient d' is nearly constant and showed slight reduction only for very high $\chi$ values (with the respective increase in the $Q$ sensitivity). However, when the reinforcement rate increases and therefore reduces the lever arm (and the reliability index), the sensitivity of $\beta$ in relation to $G$ and $Q$ becomes smaller.

In the case of steel beams designed according to NBR8800 [3], the results (Figure 11) show reliability index values relatively low compared to the limits mentioned, especially for loading ratios $\chi>0.8$.

In [3], the only difference between types I and II building is the partial

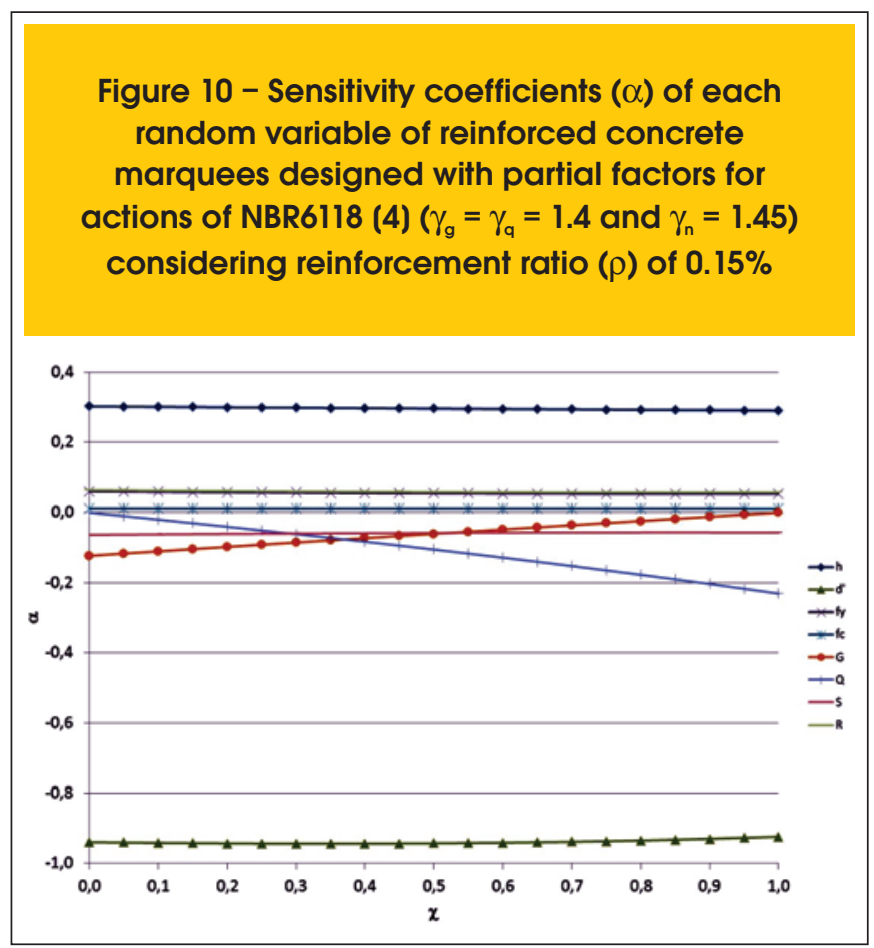


Figure 11 - Reliability index of a steel beam with compact section and laterally restrained, designed with partial factors of NBR8800 (3) for types I and II buildings

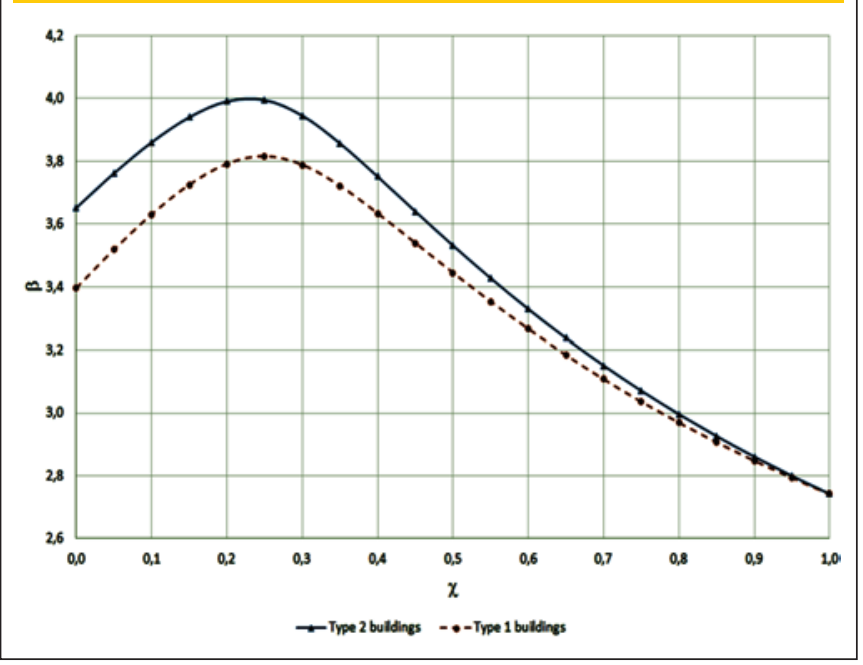

factor applied to permanent actions and therefore the two curves shown in Figure 11 do not intersect. This means that the reliability indexes at the limit between the two types of buildings are different, i.e., there is a discontinuity in the indexes obtained from the requirements of [3].

The results obtained for steel-concrete composite beams are shown in Figure 12. It was observed that the reliability indexes are between values obtained for the reinforced beams section and those obtained for steel beams.

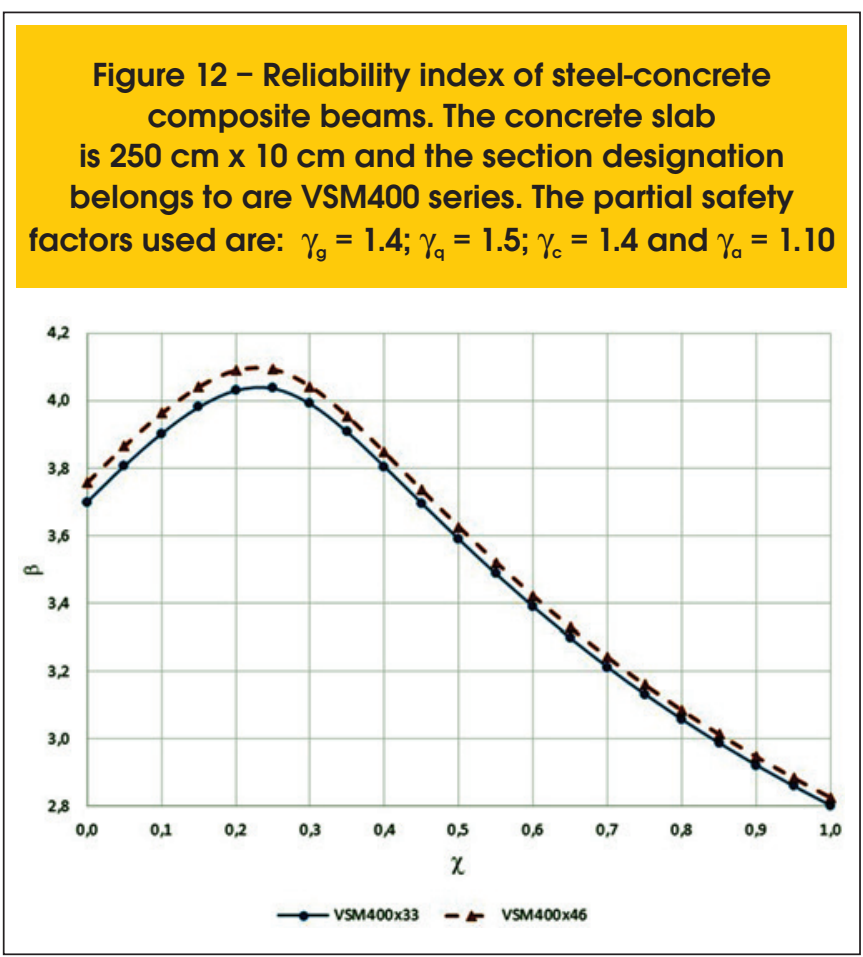

Using the same partial factor of steel strength of NBR6118 [2] for beams, reliability indexes similar to those obtained for reinforced concrete section were obtained, as shown in Figure 13.

\section{Conclusions}

This paper presented a comparative study of the safety of reinforced concrete, steel and steel-concrete composite beams designed according to Brazilian standards for structural design.

Results show that the reliability of reinforced concrete beams designed by NBR6118 [2] is compatible with international requirements. However, for large load ratios $(\chi>0.5)$, the reliability indexes decrease greatly, and the use of coefficients of NBR8681 is recommended [1].

For slabs under positive moment, acceptable reliability index values were also found. In the case of cantilever slabs, the reliability indexes found herein were much lower than desirable. The use of an additional safety factor (already suggested for the revision of NBR6118 [4]) is recommended. Further investigations are necessary to achieve appropriate safety to this type of structural element.

Results obtained for steel beams show acceptable reliability indexes for much of $\chi$ ratios, but very low indexes for $\chi>0.8$. It was observed that in general, the reliability indexes for steel beams are smaller than those obtained for concrete beams. The reliability indexes of steel-concrete composite beams are found between reinforced concrete beam and a steel beam. This is partly because the partial factors for reinforcement $\left(\gamma_{\mathrm{s}}=1.15\right)$ and for structural steel $\left(\gamma_{a}=1.10\right)$ are different.

In general, a very large variation or lack of uniformity of reliability indexes obtained for different loading ratios and for different materials was observed. These results demonstrate the importance of performing reliability-based calibration of partial safety factors for Brazilian standards, as observed for American and European stan-

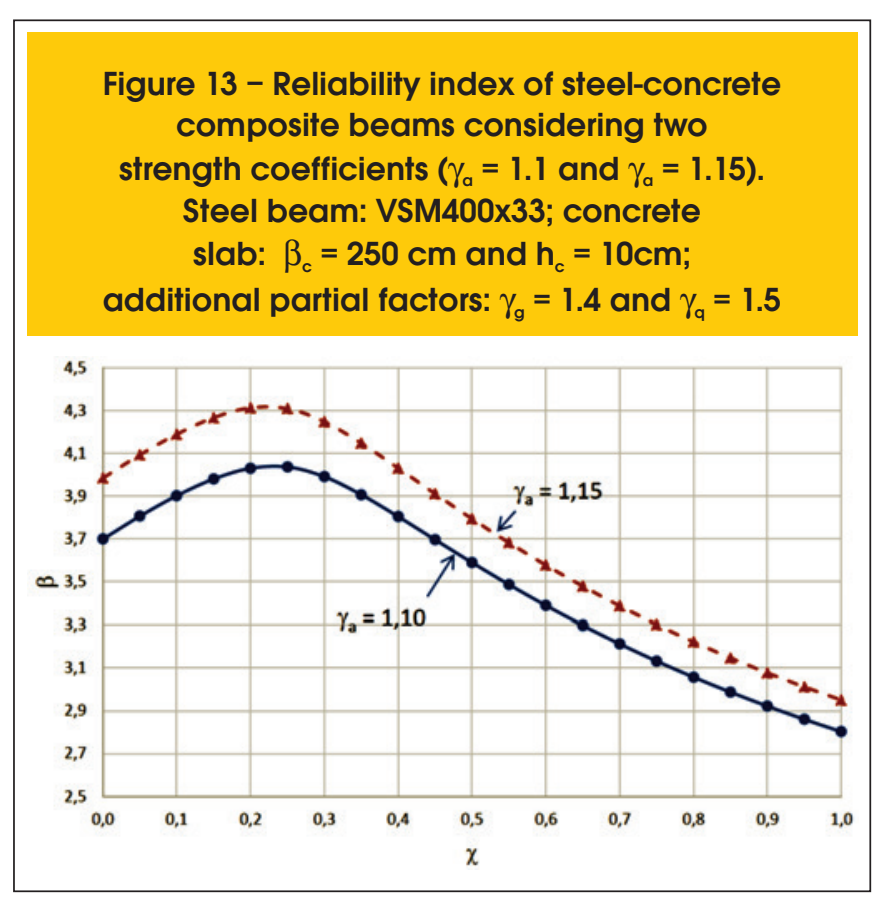


dards. Efforts in this direction have already been made by Beck and Souza Jr. [11] and will continue to be the subject of further studies. As previously mentioned, studies should investigate these variations for all usual structural elements, identifying and correcting problems as those of cantilever concrete slabs and columns with very small dimensions. In this context, pillars, which are the most important elements for the sustaining of buildings, should also be considered and have a large number of cases not only by the large variation of the moment / normal ratio and oblique bending, but also due to their slenderness.

\section{Acknowledgments}

The third author thanks CNPq for the research scholarship granted, which supported his dedication to this research project.

\section{References}

[01] ASSOCIAÇÃO BRASILEIRA DE NORMAS TÉCNICAS. Ações e segurança nas estruturas - procedimento. NBR8681, Rio de Janeiro, 2003.

[02] ASSOCIAÇÃO BRASILEIRA DE NORMAS TÉCNICAS. Projeto de estruturas de concreto - procedimento. - NBR6118, Rio de Janeiro, 2007.

[03] ASSOCIAÇÃO BRASILEIRA DE NORMAS TÉCNICAS. Projeto de estruturas de aço e de estruturas mistas de aço e concreto de edifícios. - NBR8800, Rio de Janeiro, 2008.

[04] ASSOCIAÇÃO BRASILEIRA DE NORMAS TÉCNICAS. Projeto de estruturas de concreto - procedimento. - NBR6118, Projeto de revisão, Rio de Janeiro, 2013.

[05] ASSOCIAÇÃO BRASILEIRA DE NORMAS TÉCNICAS. Cargas para o cálculo de estruturas de edificações. - NBR6120, Rio de Janeiro, 1980.

[06] ASSOCIAÇÃO BRASILEIRA DE NORMAS TÉCNICAS. Forças devidas ao vento em edificações. - NBR6123, Rio de Janeiro, 1988.

[07] ASSOCIAÇÃO BRASILEIRA DE NORMAS TÉCNICAS. Projeto e execução de estruturas de concreto pré-moldado. - NBR9062, Rio de Janeiro, 2006.

[08] ASSOCIAÇÃO BRASILEIRA DE NORMAS TÉCNICAS. Dimensionamento de estruturas de aço constituídas por perfis formados a frio. - NBR14762, Rio de Janeiro, 2010.

[09] ASSOCIAÇÃO BRASILEIRA DE NORMAS TÉCNICAS. Projeto de estruturas de concreto em situação de incêndio. - NBR15200, Rio de Janeiro, 2010.

[10] ASSOCIAÇÃO BRASILEIRA DE NORMAS TÉCNICAS. Dimensionamento de estruturas de aço de edifícios em situação de incêndio - procedimento. - NBR14323, Rio de Janeiro, 1999.

[11] BECK, A.T.; SOUZA Jr, A.C. "A first attempt towards reliability-based calibration of Brazilian structural design codes". J. of the Braz. Soc. of Mech. Sci. \& Eng. 32, 119-127, 2010.

[12] STUCCHI, F. R.; SANTOS, S. H. C.Evaluation of the Safety Criteria of Brazilian Standard NBR 6118 Based on Reliabilty Analyses. In: Joint IABSE fib Conference: Codes in Structural Engineering, Dubrovinik, 2010.

[13] STUCCHI, F. R.; SANTOS, S. H. C. Reliability based comparison between ACI 318-05 and NBR 6118. Revistalbracon de Estruturas, São Paulo, v. 3, n. 2, 2007.
[14] SILVA, J.L.; ELDEBS, M.K.; BECK, A. T.Reliability Evaluation of Reinforced Concrete Pipes in Crack Opening Limit State. IBRACON Structures and Materials Journal. , v.1, p.314 - 330, 2008.

[15] SANTIAGO, W.C.; BECK, A. T. A study of Brazilian concrete strength (non-)compliance and its effects on reliability of short columns. Revista IBRACON de Estruturas e Materiais, v.4, p.663 - 690, 2011.

[16] STUCCHI, F. R.; MORAIS, F. L. Análise probabilística da Segurança de vigas de concreto armado submetida à flexão simples, com o uso da teoria da confiabilidade e do método de Marte Carlo. In: VI Simpósio na EPUSP sobre estruturas de concreto, São Paulo, 2006.

[17] BECK, A.T.; DÓRIA, A.S. "Reliability analysis of I-section steel columns designed according to new Brazilian building codes". J. of the Braz. Soc. of Mech. Sci. \& Eng. 30, 152150,2008

[18] OLIVEIRA, W.L.A.; BECK, A. T.;EL DEBS, A.L.H.C.Safety evaluation of circular concrete-filled steel columns designed according to Brazilian building code NBR 8800:2008. Revista IBRACON de Estruturas e Materiais. , v.1, p.212 - 236, 2008.

[19] BECK, A. T.; OLIVEIRA, W. L. A.; De NARDIN, S.; EL DEBS, A. L. H. C. "Reliability-based Evaluation of Design Code Provisions for Circular Concrete-Filled Steel Columns". Engineering Structures 31(10), 2299-2308, 2009.

[20] ELLINGWOOD, B. R.; GALAMBOS, T. V. "Probability-based criteria for structural design." StructuralSafety 1, 15-26, 1982.

[21] NOWAK, A. S.; SZERSZEN, M. Calibration of design code for buildings (ACI 318): Part 1 - Statistical models for resistance. ACl structural Journal, New York, v. 100 , n. 3, p. 377382, 2003.

[22] SZERSZEN, M.; NOWAK, A. S. Calibration of design code for buildings (ACI 318): Part 2 - Reliability analysis and resistance factors. ACl structural Journal, New York, v. 100, n. 3, p. 383-391, 2003.

[23] JCSS - JOINT COMMITTEE ON STRUCTURAL SAFETY. Probabilisticmodelcode. Disponível em http://www.jcss.byg. dtu.dk/, 2002.

[24] GULVANESSIAN, H.; HOLICKÝ, M. Reliability based calibration of eurocodes considering a steel member. JCSS Workshop on Reliability Based Calibration, 2002.

[25] GULVANESSIAN, H.; HOLICKÝ, M. Eurocodes: using reliability analysis to combine action effects. Structures \& Buildings, V. 158, n. SB4, 2005.

[26] HOLICKÝ, M.; MARKOVA, J. Safety of concrete structures in accordance with eurocodes. Proceedings of the 2nd intenational fib congress, Naples, Italy, 2006.

[27] HOLICKÝ, M. et al. The reliability basis of design for structural resistance. Proceedings, 3rd International Conference on Structural Engineering, Mechanics and Computation, Cape Town, 2007.

[28] BECK, A.T. "Computer-aided teaching of structural reliability". Proceeding of 28th Iberian Latin-American Congress on Computational Methods in Engineering, Porto, Portugal, 2007.

[29] EUROPEAN COMMITTEE FOR STANDARDIZATION. Eurocode0: Basis of structural design.EN 1990, Brussels, 2004. 
[30] MADSEN HO, KRENK S, LIND NC. Methods of structural safety. Prentice Hall, Englewood Cliffs, 1986.

[31] MELCHERS RE. Structural Reliability Analysis and Prediction". John Wiley \& Sons, Chichester, 1999. 